S. Kopashynskii ${ }^{1}$, O. Serpukhov ${ }^{2}$, H. Makogon ${ }^{2}$

${ }^{1}$ The National Defense University of Ukraine named after Ivan Cherniakhovskyi, Kyiv, Ukraine

${ }^{2}$ Military Institute of Tank Troops of National Technical University, Kharkiv, Ukraine

\title{
THE USE OF "ELECTRONIC CLOUD" TECHNOLOGY TO IMPROVE THE FUNCTIONING OF THE RECOVERY SYSTEM OF ARMORED WEAPONS AND EQUIPMENT
}

\begin{abstract}
The subject matter of the article is the process of the system of recovery of armored weapons and equipment functioning in the performance of tasks for the purpose in modern conditions. The goal of the study is to create a decision support system for the recovery of armored weapons and equipment under the interactive analysis of temporal and spatial indicators of warfare based on the use of "electronic cloud " technology. The tasks to be solved are: to formulate tasks effectiveness will increase in the decision support system; to develope structural and functional-logical scheme of the system, the list of external, calculation and control modules; to determinate the volume and format of input and output information for each structural unit and information buses of the system; to define the format of protocols for information exchange, the content of "survey" cards. General scientific and special methods of scientific knowledge are used.On the basis of a systematic analysis of the existing of armored weapons and military equipment recovery system, the main conditions and factors affect its functioning in modern armed conflicts were determined. The following results are obtained. The synthesis of the structural and logical scheme of the decision support system "virtual headquarters" in the form of software with modular architecture was carried out. Conclusions. Today, not only the process of positioning forces and means of technical support and their rational placement relative to military units, but also rapid response to changes in the technical situation is complicated. Improving the quality of the of weapons and military equipment recovery system is possible by creating a decision support system "Virtual headquarters". The main idea of creating the system is the processing of incoming and outgoing information in interactive mode, operational and optimal management of information flows and visualization of the solution for the recovery of weapons and military equipment. The proposed modular system architecture provides a list of external, design and management modules; the scope and format of input and output information for every business unit and information system buses. The information space, where the system resources will be located, is proposed to be built using the "electronic cloud" technology.
\end{abstract}

Keywords: recovery of armored weapons and millitary equipment; decision support system; virtual headquarters; electronic cloud.

\section{Introduction}

Formulation of the problem and research tasks. Today, the war has acquired a hybrid character, it is conducted in all areas using the latest technologies and weapons. Modern combat operations are characterized by dynamism, maneuverability, sharp changes in the situation, fighting in the depths of the enemy's defense with the use of reconnaissance and sabotage groups, artillery and mineexplosive barriers, etc. This causes a wider use of various types of weapons and military equipment, ammunition and military equipment. In these conditions they are such troops technical support activeness at performance of tasks on purpose as a subsystem of recovery that directly affect the ability of troops to perform tasks in the prescribed volumes and terms.

In modern Conditions not only the process of positioning forces and means of technical support and their rational placement relative to military units, but also rapid response to changes in the technical situation is complicated. The above indicates the relevance of the study and the need to form an approach to the organization of the armored weapons and military equipment (AWME) recovery system based on a combination of scientific methods and the latest information technologies for calculations and justification of the decision in the conditions of interactive analysis of temporal and spatial indicators of warfare.

Analysis of recent research and publications on the above issues shows the relevance of this one.
According to experts and the analysis of information from open sources, the functioning of the AWME recovery system in modern armed conflicts has certain features. In works [1-11] the characteristic of the existing recovery system is given, an assessment of the effectiveness of its functioning is shown, the influence of external and internal factors on the organization of the process of recovering the equipment is determined.

As it is known the recovery system is assigned a lot of different content and complexity of the work, which is functionally distributed to the technical exploration, repair and evacuation of the AWME. Experts substantial the questions assess the evacuation capabilities of the repair and recovery units for the damaged armored weapons and military equipment samples, the choice of criteria for assessing the technological efficiency of recovery methods of components and rational method of recovery of details, taking into account the technological and economic characteristics of a particular repair enterprise. In addition, specialists offer options for determining the topological structure (the number of repair units, their location) and functional structure (division by levels of the system of tasks for maintenance and repair (MR), their solutions and MR sets), calculation of the optimal leverage the costs of moving the AWME, and the entire amount of work on the MR would be performed in a timely manner $[12,13]$. However, there is no systematic combination of these techniques to solve the problems of improving the efficiency of the recovery system of AWME. 
The goal of this work is creation of a decision support system for the recovery of AWME in the conditions of interactive analysis of temporal and spatial indicators of warfare based on the use of "electronic cloud" technology. To achieve this goal the following research tasks are solved: formulation of problems, the effectiveness of which will increase in the system of support of decision-making; development of structural and functional-logic system, the external, operating and control modules; determine the scope and format of input and output information for every business unit and information system buses; and the development of information exchange protocols, the content of the "survey" cards. General scientific and special methods of scientific knowledge are used.On the basis of a systematic analysis of the existing of AWME recovery system, the main conditions and factors affect its functioning in modern armed conflicts were determined.

\section{Main material}

1. Architecture of decision support system (DSS) "Virtual headquarters". In a general sense, the task of the DSS is to provide the decision maker with the information needed to make individual and group decisions based on computer processing.

The effectiveness of the use of the DSS is due to its ability to consider a significant number of alternatives in a short time, to use models for both analysis and assessment of the consequences of the decision. The architecture of the DSS, as a rule, combines three systems: analysis, information and calculation and solution formation [14-18].

Based on the definition that the AWME recovery system includes forces and means united by a single goal of maintaining this equipment in good condition and in constant readiness for use, it is advisable to assign the following tasks to the "Virtual headquarters" DSS:

collection and primary processing of data for the implementation of evacuation measures;

- possibilities assessment of the repair and restoration units for the evacuation of damaged AWME samples;

selection of criteria for assessing the technological efficiency of methods of recovery of AWME;

$\square$ forecasting of volumes of tasks that are assigned to repair and recovery units during operation (military operations);

$\square$ justification of logistic support of militarytechnical property;

$\square$ visualization of information for the decision maker and formation of initial information in the users desired format.

The main idea of creating the system is proposed to consider its functioning in real time, processing of incoming and outgoing information in interactive mode, operational and optimal management of information flows and visualization of solutions for the recovery of weapons and military equipment.

For this purpose, the information space, the system resources will be located, is proposed to be built using the "electronic cloud" technology.

The ability of "connecting" to this cloud will have machine commanders via GPS communication, drones automated technical intelligence and external users.

Thus, according to the functional purpose we define software-calculation, reference, input / output information and control modules. It is proposed to introduce the following modules (Fig. 1):

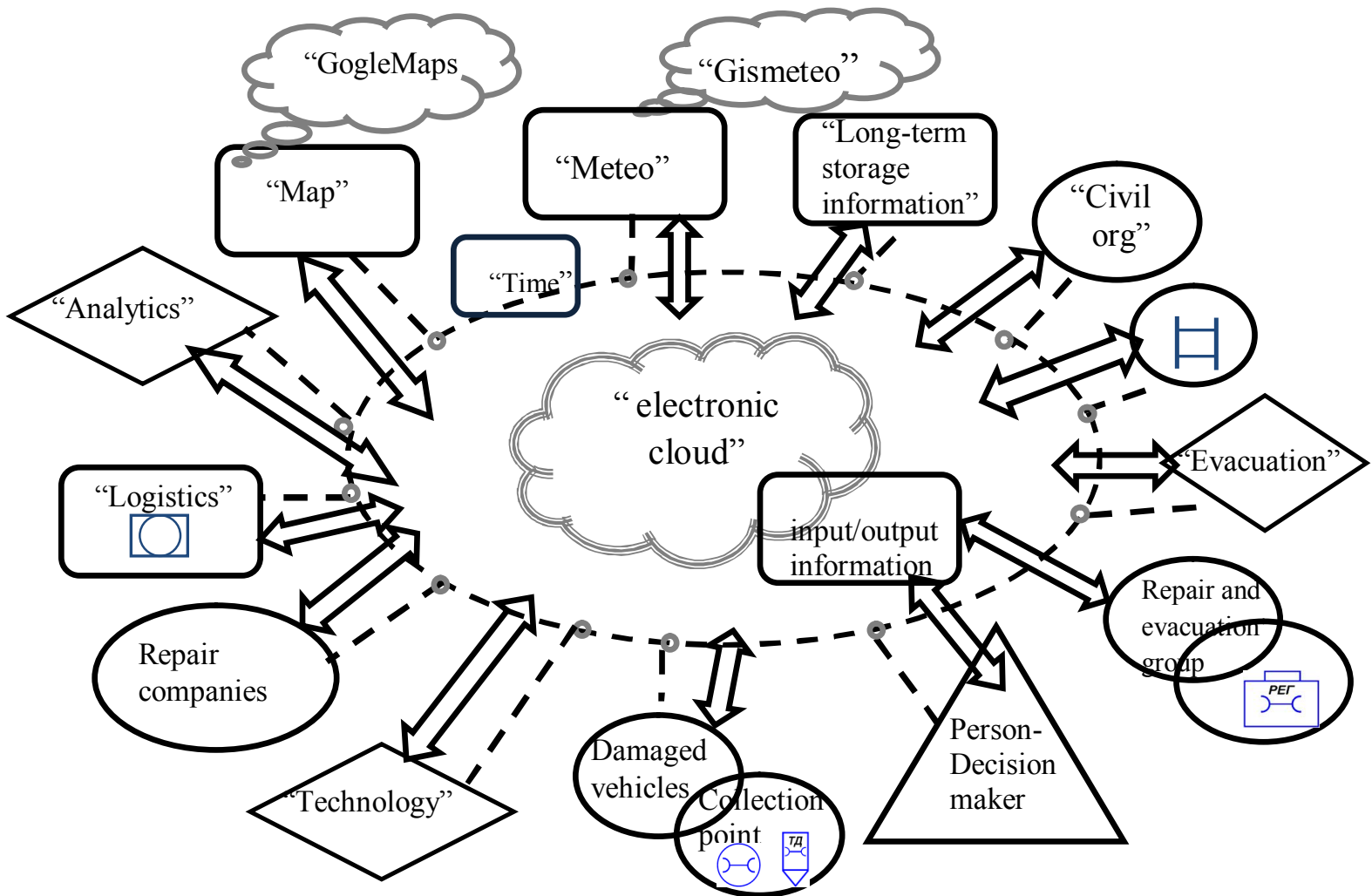

Fig. 1. Structural and functional diagram of the "Virtual Headquarters" decision support system 
- input/output of information: data exchange with technical assistance points and collection of damaged vehicles; communication with relevant civil organizations;

- reference modules: meteorological conditions "Meteo"; terrain maps "Map" and long-term storage information "Technique";

- software and calculating modules: "Evacuation", "Technology", "Analytics", "Logistics", the interaction of which will allow in real time to form solutions for the recovery of AWME, to determine the optimal mode of recovery of a sample of equipment with priority from urgent to regular, as well as for the operational solution of the problems of protection of the AWME.

- control module "time", which performs chronometric control of the automated system. On signals of this module it is offered to carry out interactive processing of information streams on time, visualization of information for the person making decisions and formation of initial information for users in the necessary format.

Modules of input/output and primary information processing. According to the results of the analysis of input information, it is proposed to determine the optimal evacuation strategy, the feasibility of towing, transportation or withdrawal of vehicles that have failed in the nearest shelters, on the evacuation route, in places of repair (restoration of combat capability) or shipment, loading them on vehicles, as well as in pulling stuck, filled up, sunken and lifting overturned vehicles with the necessary preparatory work.

Namely:

data to determine:

the location;

the state of equipment to be evacuated;

the amount of preparatory work and types of jams.

We'd like to notice the input information is heterogeneous in nature of the measurement values, the form of representation (discrete, analog, binary). Analysis and processing of input information from the entire number of sources must be carried out simultaneously, so to improve the efficiency of this process, it is proposed to use the mathematical apparatus of probability theory and operations research.

The mathematical implementation of this process is proposed to be carried out in a special module for processing input information. The operation of this module is proposed by information exchange protocols and "survey" cards contain data on the equipment to be evacuated.

Namely:

- data to determine the location of

- state of equipment to be evacuated,

- volume of preparatory works,

- types of jams.

The commander of the unit repair and recovery groups, in turn, will have information regarding the towing, transportation or machines that have failed in the nearest shelter, to escape routes, places of repair (restoration of combat capability) or shipment, loading them on vehicle, as well as in pulling stuck, buried, sunken and lifting overturned cars with the necessary preparatory work.

Of course, a necessary condition for the implementation of the proposed idea is the reequipment of technical intelligence groups and unit repair and recovery groups, with the latest multimedia technology and communications, which is natural in the period of Informatization and computerization of society; it is also possible to use UAVs.

It is assumed that the output information, depending on user requests, can be formed in both text and graphic format at different time intervals. To do this, a special module has been introduced into the system, in which, with the help of interaction with reference and software-calculation modules of the system, information is visualized for the decision-maker and the formation of initial information for users in the desired format.

Reference modules are proposed to be introduced for the organization of access to databases of typical faults and/or jams and suggestions for solving the identified problems.

The authors assume that the modules of meteorological conditions "Meteo" and maps of the area "Map" will use the resources of known mapping services and technologies, but with the use of cashing procedures and MIP-mapping [19].

Cash copies of map messages of different scaling levels are stored in the "Map" module and are used by control signals when there is a request for visualization of map service information.

In this process, improving the image quality of map sheets with different levels of detail is carried out by using textures with different resolutions for different objects of the same image, depending on their size and depth.

Software and calculation modules. The search for optimal solutions for the displacement AWME and the use of the units of technical support, including their composition and equipment is resolved in software calculation module "Evacuation". The proposed definition of the topological structure (the number of MR agencies and their location) and functional structure (division into levels of tasks in MR system, MR kits, the calculation of the optimal leverage, in which the costs of displacement AWME, and the entire scope of work in MR would be completed on schedule, which is possible with the use of GIS technology module ("Map").

Assessment of the capabilities of repair and recoverystoration units for the evacuation of damaged AWME samples will be solved in the module "Analytics" by calculating the ratio of the number of damaged AWME samples, requiring evacuation, means of each repair and recovery unit to the actual number of evacuated ones.

The calculation model includes several stages: the first: the length of the evacuation route is calculated when using the type of evacuation means that it is advisable to have for the evacuation of the number of AWME samples; second - is determined by the ratio of the length of the escape route for the kind of emergency 
funds to the amount of escape routes in all types of emergency vehicles; the third stage is the calculation of the length of the escape route for the types of evacuation vehicles in the evacuation part of the combined evacuation groups.

The input data for the evaluation of the implementation of measures on evacuation are: the speed of a type of emergency vehicles in movement to the location of the damaged AWME samples; the speed of the evacuation (transportation) of the damaged sample by evacuation means; number of emergency funds, the loss coefficient of time in the process of evacuation, time of evacuation means; the total length of the escape route [20].

The choice of a rational recovery method of details, technology of recovery in field conditions, taking into account technological and economic features of the concrete repair enterprise of Ministry of Defence of Ukraine is supposed to be realized through definition of criterion of technological efficiency of a recovery method of accessories in the module "Technology".

The effectiveness of a particular recovery method is proposed to be determined by optimizing the criterion of technological efficiency by the method of weight functions or by the method of compromises for a particular repair unit.

The essence of the method of weight functions is that each indicator that affects the final result of the solution is assigned a "weight" value.

The criterion of efficiency in this case is a function of the weight indicators of the methods for each of the options.

The variant with the extreme value of the criterion will be optimal $[12,21]$.

In the module "Logistics" the authors consider the realizing of the method determine the choice of optimal variant of forces and means of repair and recovery units distribution on topological field repair and recovery AWME samples the criterion of the most effective from the point of view of costs minimization distribution between the points of repair of military equipment and other material resources necessary for remediation. This problem is formulated as a classical distribution problem of transport type, the solution of which is proposed to be carried out by using the known mathematical apparatus of linear programming. During the calculations, the transport costs of the distribution of military-technical property and other material assets, the dimensions of the topological field and the coordinates of the repair points of AWME samples are considered known [22].

\section{Conclusions and prospects for further research}

1. Today, not only the process of positioning forces and means of technical support and their rational placement relative to military units, but also rapid response to changes in the technical situation is complicated.

2. Improving the quality of the weapons and military equipment recovery system is possible with a combination of scientific methods and the latest information technologies for calculations and justification of the decision under the interactive analysis of temporal and spatial indicators of warfare by creating a decision support system "Virtual headquarters"

3. DSS "Virtual headquarters" will increase the efficiency of solving such problems in the recovery AWME as collection and primary data processing for the evacuation of damaged AWME samples, evaluation of repair and recovery units opportunities, technological efficiency of AWME recovery methods; forecasting volumes of tasks assigned to the repair and recovery units during the operation (combat actions); support logistics for the military-technical property; visualization of information for decision-makers and the formation of the source of information for users in the desired format.

4. The main idea of creating the system is the processing of incoming and outgoing information in interactive mode, operational and optimal management of information flows and visualization of the solution for the recovery of weapons and military equipment.

5. The proposed modular system architecture provides a list of external, design and management modules; the scope and format of input and output information for every business unit and information system buses. The information space, where the system resources will be located, is proposed to be built using the "electronic cloud" technology.

6 . The creating of the DSS involves the work of a team includes specialists from various industries: ITspecialists will develop exchange protocols, military management specialists - information exchange procedures, etc. Futher authors plan to carry out the development of functional links and structural interaction between the elements of the system, as well as the protection of information flows.

Forecasting the volume of tasks that are assigned to the repair and recovery units during the execution of tasks for their intended purpose is possible with the help of the mathematical apparatus of the theory of Queuing.

\section{REFERENCES}

1. Shynkarenko, Yu.M., Chernykh, I.V. and Tkachenko, A.A (2011), "Determining directions for improving the efficiency of restoration of engineering equipment in combat and operations", Trudy universytetu, vol. 7, no. 106, pp. 233-236.

2. Ovcharenko, I.V. (2012), "A methodological approach to identifying capabilities of technical intelligence bodies in the course of a defensive battle", Trudy universytetu, vol. 1, no. 107, pp. 109-113.

3. Chornyy, M.V. and Dolgov, R.V. (2011), "Assessment of the problem of decision making on technical support of military formation", Viyskovo-tekhnichnyy zbirnyk, vol. 5, pp. 145-148.

4. Kuchuk G., Kovalenko A., Komari I.E., Svyrydov A., Kharchenko V. (2019), "Improving big data centers energy efficiency: Traffic based model and method", Studies in Systems, Decision and Control, vol 171. Kharchenko, V., Kondratenko, Y., Kacprzyk, J. (Eds.). Springer Nature Switzerland AG, Pp. 161-183. DOI: http://doi.org/10.1007/978-3-030-00253-4 8 
5. Svyrydov, A., Kuchuk, H., Tsiapa, O. (2018), "Improving efficienty of image recognition process: Approach and case study", Proceedings of 2018 IEEE 9th International Conference on Dependable Systems, Services and Technologies, DESSERT 2018, pp. 593-597, DOI: http://dx.doi.org/10.1109/DESSERT.2018.8409201

6. Ruban, I., Kuchuk, H., Kovalenko, A. (2017) "Redistribution of base stations load in mobile communication networks", Innovative technologies and scientific solutions for industries, No 1 (1), P. 75-81. DOI : https://doi.org/10.30837/25229818.2017.1.075.

7. Kuchuk G., Nechausov S., Kharchenko, V. (2015) "Two-stage optimization of resource allocation for hybrid cloud data store", International Conference on Information and Digital Technologies, Zilina, P. 266-271. DOI: http://dx.doi.org/10.1109/DT.2015.7222982

8. Merlac V., Smatkov S, Kuchuk N, Nechausov A. (2018) "Resourses Distribution Method of University e-learning on the Hypercovergent platform", Conf. Proc. of 2018 IEEE $9^{\text {th }}$ International Conference on Dependable Systems, Service and Technologies. DESSERT'2018. Ukraine, Kyiv, May 24-27, 2018. - P. 136-140. - DOI: http://dx.doi.org/ 10.1109/DESSERT.2018.8409114

9. Yaloveha, V., Hlavcheva, D., Podorozhniak, A. and Kuchuk, H. (2019), "Fire hazard research of forest areas based on the use of convolutional and capsule neural networks", IEEE 2nd Ukraine Conference on Electrical and Computer Engineering, UKRCON 2019 - Proceedings, DOI: http://doi.org/10.1109/UKRCON.2019.8879867

10. Kuchuk, H., Kovalenko, A., Ibrahim, B.F. and Ruban, I. (2019), "Adaptive compression method for video information", International Journal of Advanced Trends in Computer Science and Engineering, pp. 66-69, DOI: http://doi.org/10.30534/ijatcse/2019/1181.22019

11. Kuchuk, N., Mohammed, A. S., Shyshatskyi, A. and Nalapko, O. (2019), "The method of improving the efficiency of routes selection in networks of connection with the possibility of self-organization", International Journal of Advanced Trends in Computer Science and Engineering, 8(1), pp. 1-6, DOI: https://doi.org/10.30534/ijatcse/2019/0181.22019

12. Gulyaev, A.V. (2010), "The choice of criteria for assessing the technological efficiency of recovery methods of armored weapons and military equipment", Systemy ozbroyennya i viyskova tekhnika, vol. 4, no. 24, pp. 36-39.

13. Chornyy, M.V. and Dolgov, R.V. (2014), "Positioning of evacuation (repair-evacuation) bodies of military formation on the ground“", Systemy ozbroyennya i viyskova tekhnika, vol. 1, no. 37, pp.88-92.

14. Sytnyk, V.F. (2004), Decision Support Systems, Tutorial tool, KNEU, Kyiv, UA, 614 p.

15. Kovalenko, A. and Kuchuk H. (2018), "Methods for synthesis of informational and technical structures of critical application object's control system", Advanced Information Systems, 2018, Vol. 2, No. 1, pp. 22-27, DOI: https://doi.org/10.20998/2522-9052.2018.1.04

16. Sviridov, A., Kovalenko, A. and Kuchuk, H. (2018), "The pass-through capacity redevelopment method of net critical section based on improvement ON/OFF models of traffic", Advanced Information Systems, Vol. 2, No. 2, pp. 139-144, DOI: https://doi.org/10.20998/2522-9052.2018.2.24

17. Kuchuk G.A., Mohammad A.S. and Kovalenko, A.A. (2011), "The parametric data transmission control method for modifying the transport protocols of wireless networks ", Information Processing Systems, No. 8 (98), pp. 211-218.

18. Kuchuk G.A., Mohammad A.S. and Kovalenko, A.A. (2011), "Method for reducing data transmission time in a wireless network", Control, navigation and communication systems, No. 3 (19), pp. 209-213.

19. Khabrov, M. (2002), Creating detailed textures using mip-map levels in Direct3D8, available at: http://GameDev.ru

20. Kovalenko, O.A. (2016), "Assessment of the capabilities of repair and restoration bodies for the evacuation of damaged weapons and military equipment”, Suchasni informatsiyni tekhnolohiyi u sferi bezpeky ta oborony, vol. 1, pp. 55-58.

21. Tretyakov, A.M., Kravchenko, I.N. and Erofeev, M.N. (2002), "A mathematical model for optimizing the selection of the technological process of restoring worn parts of construction and road machines", Stroitelnyye i dorozhnyye mashiny, vol. 11, pp. 26-29.

22. Zykov, I.S., Kuchuk, N.H. and Shmatkov S.I. (2018), "Synthesis of architecture of the computer transaction management system e-learning", Advanced Information Systems, Vol. 2, No. 3, pp. 60-66, DOI: https://doi.org/10.20998/2522-9052.2018.3.10

23. Makogon, O.A., Prichina, V.P., Sopitko, O.V., Lagunov, O.V. and Chornobay, V.M. (2019), "Expanding the capabilities of moving repair and rehabilitation bodies by applying a logistical approach to logistical support for the repair and recovery of weapons and military equipment", Joint actions of military formations and law enforcement agencies of the state: problems and prospects, Odesa, UA, 12-13 September 2019, p. 205.

Received (Надійшла) 30.09.2019

Accepted for publication (Прийнята до друку) 06.11.2019

\section{ВідОмості ПРО Авторів / АвоUт тHE Authors}

Копашинський Сергій Анатолійович - начальник кафедри технічного забезпечення інституту оперативного забезпечення та логістики, Національний університет обоони України імені Івана Черняховського, Київ, Україна;

Serhiy Kopashynskii - Head of Technical Security Institute of Operational Security and Logistics Department, National Defense University of Ukraine named after Ivan Cherniakhovskyi, Kyiv, Ukraine; e-mail: kopashinskyas@gmail.com; ORCID: https://orcid.org/0000-0002-0117-0664

Серпухов Олександр Васильович - кандидат технічних наук, старший науковий співробітник, начальник інституту, Військовий інститут танкових військ Національного технічного університету “ХПІ”, Харків, Україна;

Oleksandr Serpukhov - Candidate of Technical Sciences, Senior Research, Head of Institute, Military Institute of Tank Troops of National Technical University "Kharkiv Polytechnic Institute", Kharkiv, Ukraine; e-mail: serpuhov1960@gmail.com; ORCID: https://orcid.org/0000-0002-5029-1016 
Макогон Олена Анатоліївна - кандидат технічних наук, доцент кафедри бронетанкового озброєння та військової техніки, Військовий інститут танкових військ Національного технічного університету “ХПІ”, Харків, Україна;

Helen Makogon - Candidate of Technical Sciences, Associate Professor of the Armored vehicles and military equipment Department, Military Institute of Tank Troops of National Technical University "Kharkiv Polytechnic Institute", Kharkiv, Ukraine;

e-mail: helmkg@,ukr.net; ORCID: https://orcid.org/0000-0003-1112-8707

\section{Застосування технології “електронної хмари” для вдосконалення функціонування системи відновлення бронетанкового озбросння і техніки \\ С. А. Копашинський, О. В. Серпухов, О. А. Макогон}

Анотація. Предметом вивчення в статті $є$ процес функціонування системи відновлення бронетанкового озброєння і техніки при виконанні завдань за призначенням в сучасних умовах. Метою дослідження $\epsilon$ створення системи підтримки прийняття рішення з відновлення бронетанкового озброєння і техніки в умовах інтерактивного аналізу часово-просторових показників ведення бойових дій на основі використання технології “електронної хмари”. Задачі: Формулювання завдань, ефективність вирішення яких підвищиться у системі підтримки прийняття рішення; розробка структурної та функціонально-логічної схеми системи, переліку зовнішніх, розрахункових та управляючих модулів; визначення обсягу та формату вхідної та вихідної інформації для кожної структурної одиниці та інформаційних шин системи; формування протоколів обміну інформацією, змісту “опитувальних" карток. Методологічною основою дослідження стали загальнонаукові та спеціальні методи наукового пізнання. на основі системного аналізу існуючої системи відновлення бронетанкового озброєння і техніки були визначені основні умови i чинники, які впливають на iї функціонування в сучасних збройних конфліктах. Отримані такі результати. Було здійснено синтез структурно-логічної схеми системи підтримки прийняття рішення "віртуальний штаб” у вигляді програмного забезпечення 3 модульною архітектурою. Висновки. Сьогодні ускладнюється не тільки процес позиціонування сил і засобів технічного забезпечення та їх раціонального розміщення відносно військових підрозділів, а і оперативного реагування на зміну технічної обстановки. Підвищення якості функціонування системи відновлення озброєння та військової техніки можливо за рахунок створення системи підтримки прийняття рішення "Віртуальний штаб”. Провідною ідеєю створення системи є обробка вхідної та вихідної інформації в інтерактивному режимі, оперативне і оптимальне управління інформаційними потоками та візуалізація рішення по відновленню озброєння та військової техніки. Запропонована модульна архітектура системи, визначений перелік зовнішніх, розрахункових та управляючих модулів; обсяг і формат вхідної та вихідної інформації для кожної структурної одиниці та інформаційних шин системи. Інформаційний простір, де будуть знаходитися ресурси системи, пропонується побудувати за технологією “електронної хмари”.

Ключові слова: відновлення бронетанкового озброєння і техніки; система підтримки прийняття рішення; віртуальний штаб; електронна хмара.

\section{Применение технологии “электронного облака" для совершенствования функционирования системы восстановления бронетанкового вооружения и техники \\ С. А. Копашинский, А. В. Серпухов, Е.А. Макогон}

Аннотация. Предметом изучения в статье является процесс функционирования системы восстановления бронетанкового вооружения и техники при выполнении задач по назначению в современных условиях. Целью исследования является создание системы поддержки принятия решения по восстановлению бронетанкового вооружения и техники в условиях интерактивного анализа временно-пространственных показателей ведения боевых действий на основе использования технологии “электронного облака”. Задачи: формулировка заданий, эффективность решения которых повысится в системе поддержки принятия решения; разработка структурной и функционально-логической схемы системы, перечня внешних, расчетных и управляющих модулей; определение объема и формата входной и выходной информации для каждой структурной единицы и информационным шинам системы; формирование протоколов обмена информацией, содержания “опросных” карточек. Методологической основой исследования стали общенаучные и специальные методы научного познания. на основе системного анализа существующей системы восстановления бронетанкового вооружения и техники были определены основные условия и факторы, которые влияют на ее функционирование в современных вооруженных конфликтах. Получены такие результаты. Был осуществлен синтез структурно-логической схемы системы поддержки принятия решения "виртуальный штаб" в виде программного обеспечения с модульной архитектурой. Выводы. Сегодня осложняется не только процесс позиционирования сил и средств технического обеспечения и их рационального размещения относительно военных подразделений, а и оперативного реагирования на изменение технической обстановки. Повышение качества функционирования системы восстановления вооружения и военной техники возможно за счет создания системы поддержки принятия решения “Виртуальный штаб”. Ведущей идеей создания системы является обработка входящей и исходящей информации в интерактивном режиме, оперативное и оптимальное управление информационными потоками и визуализация решения по восстановлению вооружения и военной техники. Предложена модульная архитектура системы, определен перечень внешних, расчетных и управляющих модулей; объем и формат входной и выходной информации для каждой структурной единицы и информационным шинам системы. Информационное пространство, где будут находиться ресурсы системы, предлагается построить по технологии “электронного облака".

Ключевые слова: восстановление бронетанкового вооружения и техники; система поддержки принятия решения; виртуальный штаб; электронное облако. 